УДК 542:92.542:97.542:943

ИССЛЕДОВАНИЕ КИНЕТИКИ ДЕСТРУКЦИИ ЛИГНИН-

ЦЕЛЛЮЛОЗНОЙ БИОМАССЫ В ВОДНОЙ СРЕДЕ

В ПРИСУТСТВИИ НАНОРАЗМЕРНЫХ ЧАСТИЦ

ОКСИДА ЖЕЛЕЗА

\title{
THE STUDY OF LIGNIN-CELLULOSIC BIOMASS DESTRUCTION \\ KINETICS IN AN AQUEOUS MEDIUM IN THE PRESENCE \\ OF IRON OXIDE NANOPARTICLES
}

\author{
В.И. Лесин, С.В. Лесин \\ Институт проблем нефти и газа РАН, г. Москва, \\ Российская Федерация
}

Viktor I. Lesin, Sergey V. Lesin

Oil and Gas Research Institute of RAS, Moscow, Russian Federation

e-mail: vilesin@inbox.ru

Аннотация. Формированию источника нефти - керогена предшествует стадия наземной деструкции органических веществ. В работе на примере древесных опилок в воде, где в качестве катализатора окислительного крекинга использовались наночастицы оксида железа, а в качестве окислителя перекись водорода, исследована кинетика деструкции лигнинцеллюлозной биомассы.

Катализатор, представляющий наноразмерные частицы оксидов железа, полученные гидролизом соли хлорного железа в воде с примесью этанола, ранее был использован как для деструкции перекиси водорода, так и для окислительного крекинга различных видов органических веществ растительного происхождения, в том числе пальмового масла и лимонена. Выбор типа катализатора был обусловлен тем, что коллоидные частицы 
оксидов железа, как правило, присутствуют в воде и нефти в качестве микропримесей.

Ранее было показано, что такой катализатор проявляет свойства природных ферментов и формирует каталитическую систему, которая способна изменять механизм окисления органических веществ в зависимости от состава среды. Однако регистрация изменений во времени состава реакционной среды, за исключением измерений концентрации перекиси водорода, не производилась.

В работе обнаружено, что деструкция как биомассы, так и перекиси водорода, при температуре $\left(60{ }^{\circ} \mathrm{C}\right)$ и атмосферном давлении вначале протекает с высокой скоростью, затем скорость падает практически до нуля на длительное время, порядка нескольких часов, после чего деструкция опять происходит с высокой скоростью. Величина $\mathrm{pH}$ водного раствора также остается постоянной при торможении распада перекиси и биомассы. В ходе деструкции содержание ряда органических кислот в реакционной смеси вначале растет, затем падает и остается постоянной в течение нескольких часов, затем снова растет по мере расходования субстратадревесных опилок.

Анализ данных позволяет высказать гипотезу о том, что такая $\mathrm{S}$-образная зависимость потери биомассы во времени вызвана первоначальной деструкцией лигнина, покрывающего волокна целлюлозы, a затем перестройкой катализатора под действием продуктов распада лигнина.

Abstract. The formation of the source of oil - kerogen is preceded by the stage of terrestrial destruction of organic substances. The kinetics of the destruction of lignin-cellulosic biomass is studied using the example of wood sawdust in water, where nano-particles of iron oxide were used as a catalyst for oxidative cracking, and hydrogen peroxide as an oxidizer.

The catalyst, which is nano-sized particles of iron oxides obtained by hydrolysis of ferric chloride salt in water with an admixture of ethanol, was 
previously used both for the destruction of hydrogen peroxide and for the oxidative cracking of various types of organic substances of plant origin, including palm oil and limonene. The choice of the type of catalyst was due to the fact that colloidal particles of iron oxides are usually present in water and oil as micro-impurities.

It was previously shown that such a catalyst exhibits the properties of natural enzymes and forms a catalytic system that can change the mechanism of oxidation of organic substances under the action of the medium composition. However, no changes in the composition of the reaction medium were recorded over time, with the exception of measurements of the concentration of hydrogen peroxide.

It was found that the decomposition of both biomass and hydrogen peroxide at a temperature $\left(60^{\circ} \mathrm{C}\right)$ and atmospheric pressure initially proceeds at a high rate, then the rate drops to almost zero for a long time of the order of several hours, after which the destruction again occurs at a high rate until the peroxide is completely consumed. The $\mathrm{pH}$ value of the aqueous solution also remains constant when the decomposition of peroxide and biomass is inhibited. In the course of the destruction, the content of a number of organic acids in the reaction mixture first increases, then falls and remains constant for several hours, then increases again.

The analysis of the data allows us to hypothesize that this S-shaped dependence of the biomass loss over time is caused by the initial destruction of the lignin covering the cellulose fibers, and then by the rearrangement of the catalyst under the action of lignin degradation products.

Ключевые слова: кероген; биомасса; лигнин; целлюлоза; оксид железа; катализатор; органическая кислота; перекись водорода; вода; температура $60{ }^{\circ} \mathrm{C}$

Keywords: kerogen, biomass, lignin, cellulose, iron oxide, catalyst, organic acid, hydrogen peroxide, water, temperature $60^{\circ} \mathrm{C}$ 
В природе лигнин-целлюлозная биомасса подвергается деструкции в результате работы, главным образом, ферментов. При этом в механизм ферментативного окислительного расщепления вовлекаются перекись водорода и кислород воздуха [1]. Однако воздействие ферментов осложняется тем, что продукты биодеградации лигнина (слабые органические кислоты, фураны, фенолы) ингибируют активность ферментов при глубоких степенях деструкции лигнина [2].

В последние годы, в связи с развитием и популярностью нанотехнологий, высокодисперсные гетерогенные катализаторы, основанные на оксидах железа, испытывают для процессов окисления и доокисления органических загрязнений в воде как кислородом воздуха [3], так и с использованием перекиси водорода - экологически безопасного окислителя [4].

В [5-8] был предложен коллоидный катализатор низкотемпературного окислительного крекинга органических молекул при атмосферном давлении на основе оксидов железа.

В [5] установлено, что синтезированные указанным способом частицы входят в число наиболее эффективных из имеющихся катализаторов распада перекиси водорода, наряду с природными ферментамипероксидазами.

$\mathrm{B}[6]$ показано, что уже при атмосферном давлении и температуре $60{ }^{\circ} \mathrm{C}$ данный катализатор позволяет полностью подвергнуть окислительной деструкции лигнин в древесных опилках, соломе и получить чистую целлюлозу.

В [7] показано, что использование катализатора ускоряет окисление кислородом пальмового масла, несмотря на присутствие в нем ингибиторов окисления в виде токоферолов. Молекулярный механизм окислительного крекинга данным катализатором меняется в зависимости от состава среды, что позволило считать катализатор самонастраивающимся [8]. 
В ряде исследований показано $[9,10]$, что наноразмерные (20 нм) частицы оксидов железа и других металлов, например никеля и кремния, понижают температуру деструкции асфальтенов под действием кислорода воздуха с $260{ }^{\circ} \mathrm{C}$ до $50-100{ }^{\circ} \mathrm{C}$. Деструкция асфальтенов регистрировалась по потере массы навески при нагреве в воздушной атмосфере, потеря массы асфальтенов происходила за счет образования газообразных продуктов.

Этот факт указывает на возможную значительную роль частиц оксидов железа в формировании керогена, а затем и нефти, в результате воздействия высоких температур и газов земной коры, содержащих углерод и водород. Разнообразие форм и состава керогена позволяет предположить, что наземный крекинг природных полимеров (лигнина и целлюлозы) играет значительную роль в создании такого разнообразия.

В [6] не проводились исследования изменений состава реакционной среды во времени в ходе расходования биомассы, за исключением контроля концентрации перекиси водорода. В данной работе была исследована кинетика расходования/накопления исходных реагентов и ряда продуктов в модельной системе, представляющей водную суспензию, состоящую из древесных опилок (лигнин-целлюлозная биомасса), природных окислителей - перекись водорода и кислород, частиц катализатора [8] размером $\approx 20$ нм. Поскольку катализатор имитирует свойства ферментов [8], была выбрана температура $60{ }^{\circ} \mathrm{C}$, при которой, как правило, сохраняют активность ферменты, разрушающие растительные остатки.

Выбор катализатора был обоснован наличием примесей оксидов железа в нефти [11]. В природе аналогичные частицы оксидов железа возникают в результате окисления двухвалентного железа в воде в присутствии продуктов органического происхождения.

\section{Экспериментальные результаты}

Катализатор готовили из реагентов и по методике $[5,6]$ путем гидролиза $10 \%$ раствора соли $\mathrm{FeCl}_{3} \times 6 \mathrm{H}_{2} \mathrm{O}$ (Merck $\mathrm{KGaA}$, Германия), в воде, 
содержащей 1 \% этанола. В качестве окислителя использовался $30 \%$ раствор $\mathrm{H}_{2} \mathrm{O}_{2}$ (чда. Реахим, Усольехимпром). Концентрация железа при приготовлении катализатора для экспериментов составляла 0,28 г/л, что обеспечивало синтез стержнеобразных частиц длиной порядка 20-40 нм и диаметром порядка 15-20 \% от длины [6].

В этих условиях за время порядка 15-20 мин образовывались коллоидные частицы красного цвета. Раствор выдерживался при остывании несколько часов при атмосферном давлении для формирования коллоидного осадка. Концентрированная суспензия таких частиц использовалась для проведения экспериментов. В результате гидролиза $\mathrm{FeCl}_{3} \times 6 \mathrm{H}_{2} \mathrm{O}$ ионы $\mathrm{Fe}$ практически полностью переходили в коллоидные частицы и не обнаруживались в водной фазе после отделения суспензии катализатора, что было установлено по качественной реакции окрашивания при добавлении тиоцианатом калия.

По данным анализа атомарного состава, определенного методом рентгеновской флуоресценции в тонком слое с помощью сканирующего электронного микроскопа (Carl Zeiss NTS, Germany), частицы катализатора (без учета атомов водорода, которые этим методом не регистрируются) имеют состав $\mathrm{Fe}(0.123) \mathrm{C}_{(0.577)} \mathrm{O}_{(0.289)} \mathrm{S}_{(0.0064)} \mathrm{Cl}_{(0.0044)}$, где цифры указывают долю числа атомов в составе частиц. Соотношение атомов железа и кислорода меньше, чем в кристаллах $\mathrm{Fe}_{2} \mathrm{O}_{3},-0,67$. Наличие углерода в составе частиц свидетельствует о том, что молекулы спирта входят в состав катализатора, вероятно, за счет адсорбции на поверхности. Отношение количества атомов углерода к количеству атомов кислорода составляет С/O $\approx 2$, что соответствует молекуле этилового спирта, использованного для приготовления катализатора. Наиболее вероятно, что молекулы $\mathrm{C}_{2} \mathrm{H}_{5} \mathrm{OH}$ образуют с поверхностными атомами $\mathrm{Fe}$ и $\mathrm{O}$ прочные координационные связи, что позволяет им не испаряться в вакууме, при котором происходит регистрация спектром рентгеновской флуоресценции в сканирующем электронном микроскопе, снабженном приставкой для регистрации 
спектров рентгеновской флуоресценции. Микропримеси $\mathrm{Cl}$ и $\mathrm{S}$, обнаруженные в частицах, вероятно, связаны с примесями хлора и серы в исходной соли хлорного железа.

Спектры порошковой дифракции для образцов частиц катализатора, использованного диапазона концентраций, представляли широкие диффузные линии, что затрудняло отнесение частиц к определенному типу кристаллов из-за искажения параметров решетки кристалла в поверхностных слоях для частиц такого малого размера. Наиболее близким типом частиц являлись наночастицы, частицы альфа-оксидов железа, имеющие красную окраску.

Идентификацию кислот и их концентрации определяли методом капиллярного электрофореза на приборе капиллярного электрофореза «Капель 105-М» фирмы «Люмекс», г. Санкт-Петербург. Концентрация перекиси водорода определялась йодометрическим методом.

Для изучения динамики расходования субстрата, представлявшего древесные опилки размером $\approx 2$ мм, с содержанием лигнина $24 \%$, были приготовлены одинаковые объемы одинаковых реакционных смесей, разлиты по пробиркам, пробирки закрыты и помещены в камеру с температурой $60 \quad{ }^{\circ} \mathrm{C} \quad$ в ячейки шейкера. Использование шейкера предотвращало оседание твердых частиц и обеспечивало однородность смеси благодаря постоянному перемешиванию. Вес древесных опилок, а также вес твердого остатка реакции крекинга биомассы определялся по достижении постоянной величины при высушивании в потоке воздуха при температуре $80{ }^{\circ} \mathrm{C}$. В ходе реакции пробирки изымались, быстро охлаждались до комнатной температуры, определялся рН водного раствора, определялись концентрации кислот и концентрация $\mathrm{H}_{2} \mathrm{O}_{2}$, определялся вес твердого остатка после высушивания. Время реакции до полного расходования перекиси водорода было определено ранее в эксперименте по крекингу реакционной смеси такого же состава. 
Массы реагентов в пробирках составляли в пересчете на 1 л объема смеси: $\mathrm{Fe}=0,28$ г, $\mathrm{H}_{2} \mathrm{O}_{2}=15$ г, опилки $=14$ г, использовался $30 \%$ водный раствор перекиси водорода. Реакционная смесь готовилась в следующей последовательности: субстрат помещался в воду при комнатной температуре, затем через 5-10 мин добавлялся катализатор в виде взвеси коллоидных частиц в водном растворе, после при перемешивании компонентов в течение 5-10 мин в раствор добавлялся водный раствор перекиси водорода. При комнатной температуре в течение 20-30 мин, которые требовались для проведения подготовки образцов, не наблюдалось заметное потребление перекиси. Затем сосуды с реагентами размещались в воздушной бане в шейкере. Заданная температура $60{ }^{\circ} \mathrm{C}$ в смеси достигалась за 10 мин.

Для проведения анализов пробирки с реагентами извлекались из термостата, и их содержимое подвергалось анализам, твердый остаток отделялся от раствора и высушивался в токе воздуха при температуре $80{ }^{\circ} \mathrm{C}$.

Поскольку частицы катализатора, полученного путем гидролиза солей $\mathrm{Fe}(3+)$ имеют положительный заряд, а волокна и частицы биомассы, как и клеточные мембраны, заряжены отрицательно, при добавлении биомассы катализатор адсорбируется на поверхности древесных опилок - субстрата [6].

При исследовании динамики расходования реагентов и накопления продуктов реакции ранее было обнаружено, что для определенных соотношений реагентов, включающих выбранные для проведения данного эксперимента соотношения, изменение содержания перекиси водорода в ходе реакции имеет S-образный характер.

На рисунке 1 (кривые 1,2) показаны изменения во времени реакции относительных масс субстрата и перекиси.

На рисунке 2 показана зависимость от времени реакции $\mathrm{pH}$ водного раствора. 


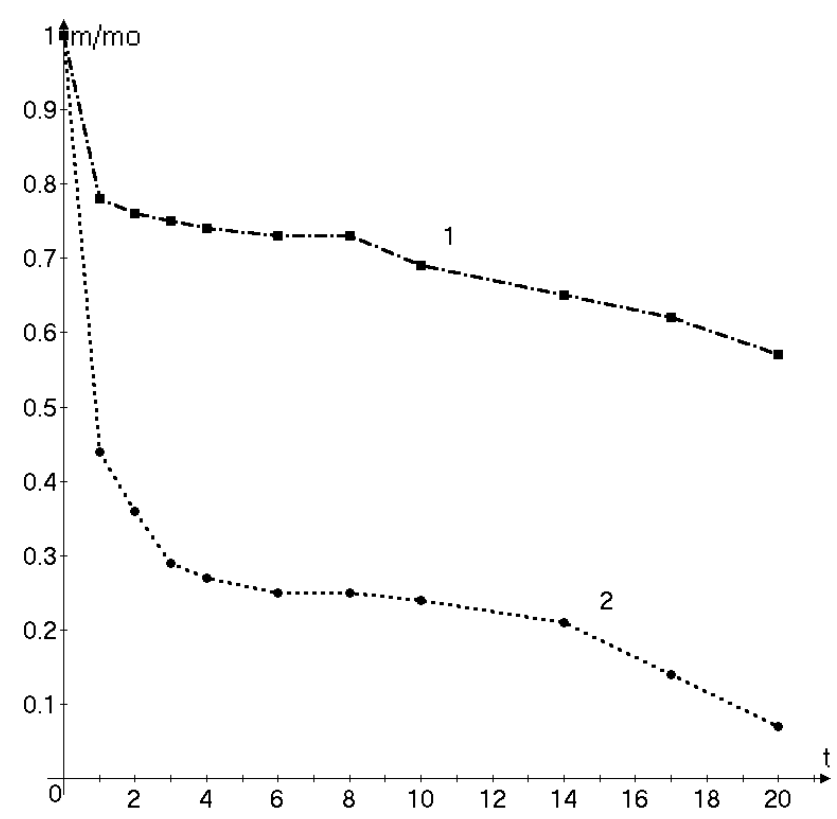

$\mathrm{m}_{\mathrm{o}}$ - исходная масса субстрата / перекиси; $\mathrm{m}$ - текущая масса субстрата / перекиси

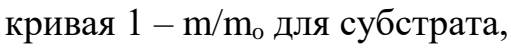

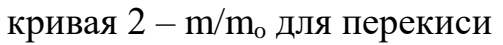

Рисунок 1. Зависимости от времени $\mathrm{t}$ (ч) начала реакции относительного содержания масс субстрата (опилок) и перекиси водорода

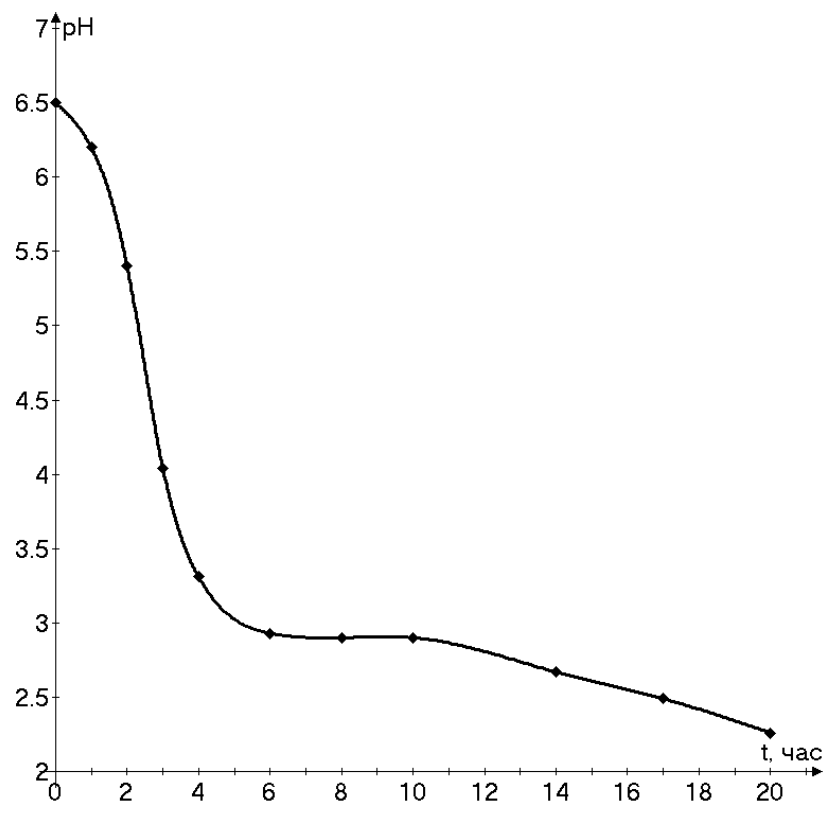

Рисунок 2. Зависимость $\mathrm{pH}$ от времени реакции $\mathrm{t}$ (ч)

На рисунках 3 и 4 показаны зависимости от времени реакции концентраций ряда органических кислот. 


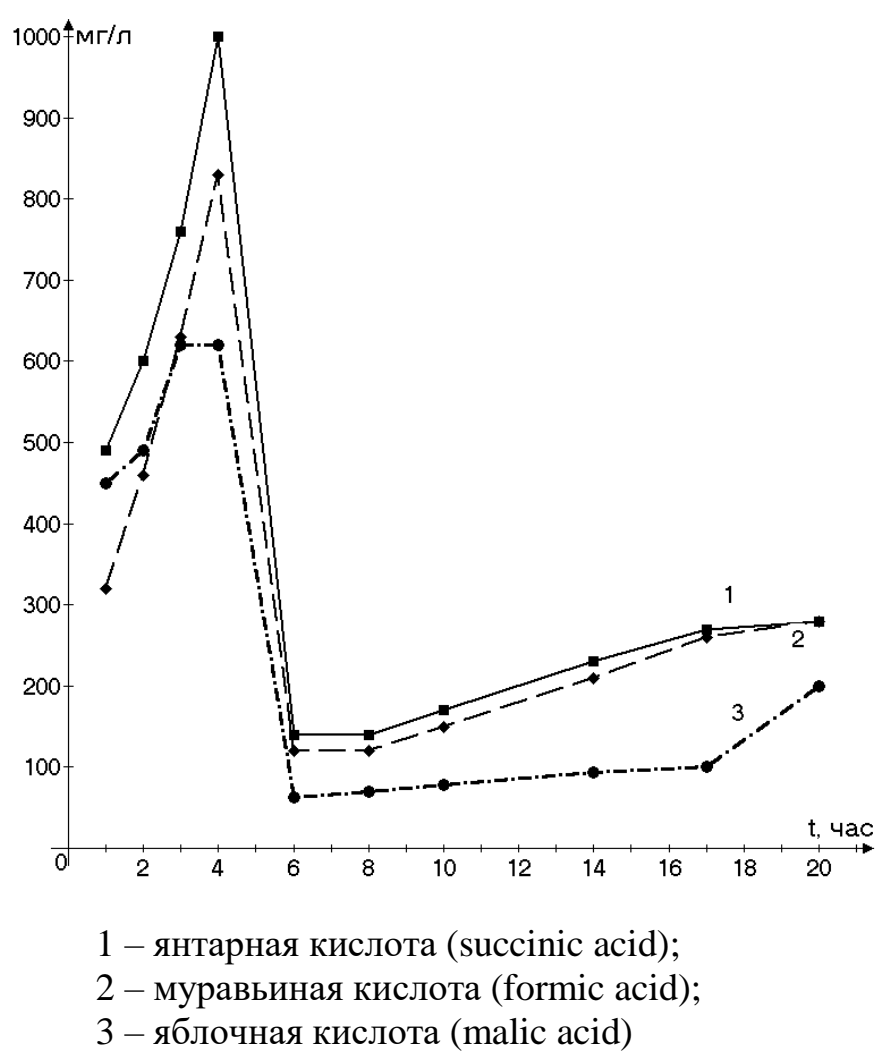

Рисунок 3. Зависимости концентраций кислот (мг/л) от времени реакции $\mathrm{t}$ (ч)

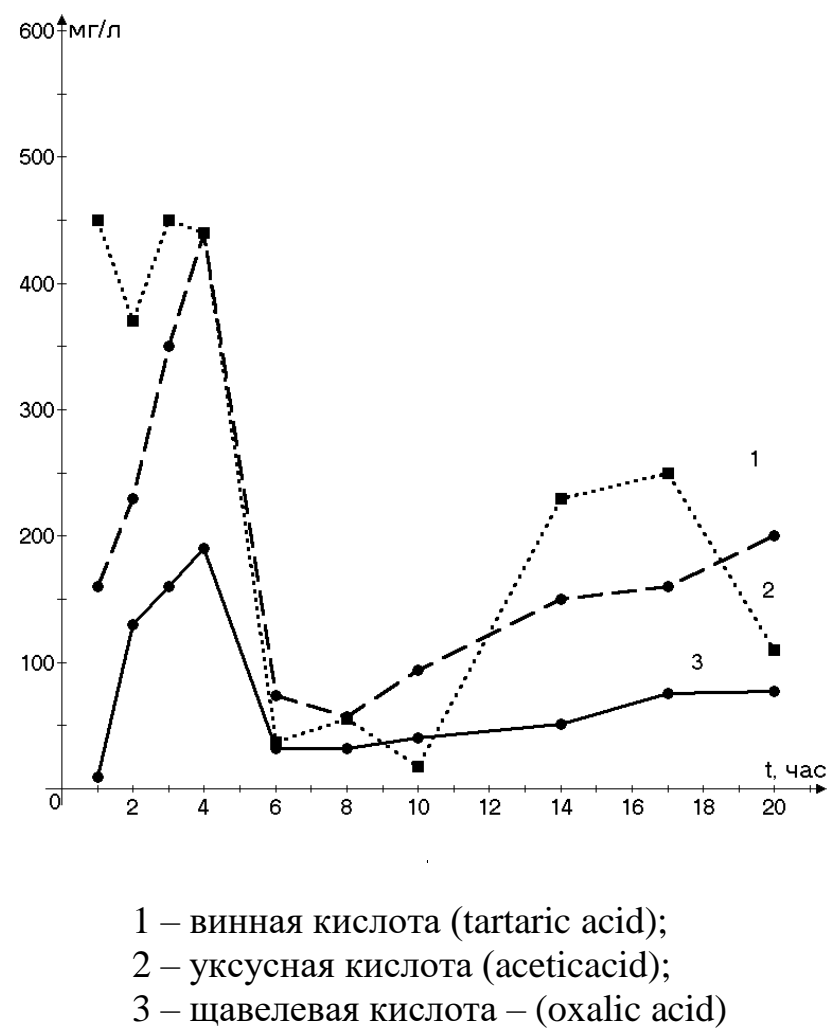

Рисунок 4. Зависимости концентраций кислот (мг/л) от времени реакции $\mathrm{t}$ (ч) 


\section{Обсуждение результатов}

Как видно из рисунка 1 (кривая 1) за первый час происходит потеря массы опилок примерно на $25 \%$, что соответствует массе лигнина в составе субстрата. Поскольку лигнин покрывает волокна целлюлозы, а кинетика реакции меняется можно считать, что эта убыль массы представляет, главным образом, массу лигнина. При этом расходуется примерно 60 \% исходной перекиси водорода, т.е. на 3,5 г лигнина расходуется 9 г перекиси водорода. При этом рН снижается на 0,2. Затем скорость потери массы твердого вещества, скорости снижения массы перекиси и величины $\mathrm{pH}$ также резко снижаются, так, что в диапазоне времени 6-8 ч в пределах точности измерений остаются постоянными. В интервале времени от 1 до 5 ч происходит рост концентраций ряда кислот (рисунки 3 и 4), суммарная концентрация кислот достигает 3,3 г/л, что близко к содержанию лигнина в субстрате. По-видимому, значительная часть перекиси водорода расходуется на образование новых соединений, вступая в реакции с лигнином.

В интервале времени 5-6 ч концентрации этих кислот резко падают и остаются примерно постоянными в интервале 6-8 ч, затем концентрации этих кислот вновь растут во времени, за исключением уксусной кислоты, концентрация которой уменьшается в интервале 18-20 ч.

Парадоксальное снижение $\mathrm{pH}$, характеризующее рост концентрации кислот $\mathrm{H}^{+}$в растворе при снижении концентраций названных выше кислот, очевидно, связано с высокой концентрацией ароматических кислот, типа бензойной, поскольку значительную массу лигнина составляют ароматические соединения.

Наблюдение за составом смеси в диапазоне времени 5-8 ч создает впечатление полной остановки реакции. Однако после 8 ч скорости расходования перекиси, массы субстрата, снижение $\mathrm{pH}$ и рост концентраций исследуемых кислот возрастают. К 20 ч реакции снижение общей массы субстрата достигает 35 \%, pH снижается до величины 2,33, масса перекиси 
водорода снижается на 6 \%. Расход перекиси водорода на потерю массы 6 \% $(\approx 1$ г) составляет $15 \%$ ( $\approx 2,3$ г). Этот этап, вероятно, соответствует крекингу и целлюлозы, поскольку твердый остаток к этому моменту имеет белосерый цвет.

Количество перекиси, затрачиваемое на крекинг лигнина $(9$ / 3,5 = 2,6) и целлюлозы близко к аналогичной величине для целлюлозы $(2,3$ / $1=2,3)$, что говорит о перестройке состава катализатора при сохранении его активности по отношению к крекингу природных полимеров лигнина и целлюлозы.

Водная часть раствора первоначально интенсивно коричневого цвета к моменту времени 15 ч приобрела слабое желто-лимонное окрашивание, что является свидетельством появления хромофорных ароматических компонентов лигнина, которые переходят в водную фазу в ходе первичного окислительного крекинга. Окисление ароматических групп лигнина, повидимому, вносит основной вклад в $\mathrm{pH}$ раствора, поэтому снижение концентрации вышеуказанных кислот не вызывает повышения рН.

Корреляция, имеющих S-образный характер, кинетических кривых расходования субстрата, перекиси водорода, $\mathrm{pH}$ и демонстрирует эффект самонастраивания катализатора за счет взаимодействия с составом внешней среды. Почти постоянные значения $\mathrm{pH}$ в диапазоне времени 6-10 час, постоянное значение массы субстрата и перекиси говорит о том, что основная масса кислот вероятно является ароматическим, поэтому снижение концентраций указанных выше кислот не приводит к росту рН.

В этом интервале времени очевидно меняется состав катализатора за счет, вероятно, формирования оксалатов $-\mathrm{FeC}_{2} \mathrm{O}_{4}$ и ацетатов железа $\left(\mathrm{CH}_{3} \mathrm{COO}\right)_{2} \mathrm{Fe}$ при реакциях со щавелевой и уксусной кислотами в кислой среде. Вероятно, и остальные кислоты взаимодействуют с первичными коллоидными частицами катализатора, формируя сложные по составу частицы нового катализатора. Поскольку органические кислоты, реагируя с 
этиловым спиртом, образуют сложные эфиры, этот процесс, по-видимому, ведет к изменению химического состава поверхности частиц катализатора.

Слабо-желтая окраска на последних стадиях реакции может быть связана с образованием мало растворимых в воде оксалатов железа, имеющих желтый цвет.

В периоде перестройки в интервале времен 4-6 ч катализатор является неактивным, что выражается в постоянстве значений $\mathrm{pH}$, массы перекиси и твердого остатка.

Активность катализатора возрастает после 6 ч, что выражается в деструкции твердого остатка, имеющего на этой стадии почти белый цвет, характерный для целлюлозы, не содержащей значительных примесей лигнина. При этом опять начинается рост концентраций исследуемых низкомолекулярных кислот, за исключением уксусной, концентрация которой уменьшается после 18 ч реакции. По-видимому, это связано с образованием растворимого в воде ацетата железа, что подтверждается слабым окрашиванием водной части раствора при добавлении тиоцианата калия.

Имитирующий активность ферментов катализатор, как видно из результатов работы, обладает способностью изменяться под действием состава внешней среды, восстанавливая активность в отношении деструкции природных полимеров. Это дает основания полагать, что значительную роль в наземной деструкции биомассы играют частицы оксидов железа, а многообразие составов керогена связано с различными стадиями деструкции биомассы, предшествующими погружению органического вещества в земную кору.

C учетом имеющихся данных представляется перспективным осуществлять окислительный крекинг керогена на основе технологий, использующих взаимодействие наноразмерных частиц оксидов железа в сочетании с нагревом. 
Отметим, что получаемая в ходе реакции водная среда является хорошей питательной средой для грибов: после длительного контакта водных растворов с воздухом даже при температуре 6-10 ${ }^{\circ} \mathrm{C}$ наблюдался рост грибковых культур различных типов. Поскольку в составе нефти обнаруживаются характерные для белковых соединений сера и азот, можно предположить, что в природе в ходе деструкции биомассы накапливаются также и органические вещества животного происхождения.

\section{Выводы}

В работе на примере древесных опилок в воде, где в качестве катализатора окислительного крекинга использовались наночастицы оксида железа, а в качестве окислителя перекись водорода, исследована кинетика деструкции лигнин-целлюлозной биомассы.

Установлено, что деструкция как биомассы, так и перекиси водорода, при температуре $\left(60{ }^{\circ} \mathrm{C}\right)$ и атмосферном давлении вначале протекает с высокой скоростью, затем скорость падает практически до нуля на длительное время, порядка нескольких часов, после чего деструкция опять происходит с высокой скоростью. Величина рН водного раствора также остается постоянной при торможении распада перекиси и биомассы. В ходе деструкции содержание ряда органических кислот в реакционной смеси вначале растет, затем падает и остается постоянной в течение нескольких часов, затем снова растет по мере расходования субстрата-древесных опилок.

Анализ данных позволяет высказать гипотезу о том, что такая S-образная зависимость потери биомассы во времени вызвана первоначальной деструкцией лигнина, покрывающего волокна целлюлозы, a затем перестройкой катализатора под действием продуктов распада лигнина. 
Авторы выражают благодарность А.Я. Масютину за оказанную техническую помощь при проведении экспериментов.

Работа выполнена в соответствии федеральной программой РАН 0139 2019-0005 (Исследование термодинамических свойств углеводородных смесей, моделирование гидротермодинамических, физико-химических и геомеханических процессов в геосредах с иелью повымения эффективности разработки трудноизвлекаемых запасов нефти и газа).

\section{Список используемых источников}

1. Lin S.S., Gurol M.D. Catalytic Decomposition of Hydrogen Peroxide on Iron Oxide: Kinetics, Mechanism, and Implications // Environmental Science and Technology. 1998. Vol. 32. P. 1417-1423. DOI: 10.1021/es970648k.

2. Kirk T.K., Farrell G. Enzymatic «Combustion»: The Microbial Degradation of Lignin // Annual Review of Microbiology. 1987. Vol. 41. P. 465-505. DOI: 10.1146/annurev.mi.41.100187.002341.

3. Kwan W.P., Voelker B.M. Decomposition of Hydrogene Peroxide and Organic Compaunds in the Presence of Iron and Ferrihydrite // Environtal Science and Technology. 2002. Vol. 36 (7). P. 1467-1476. DOI: 10.1021/es011109p.

4. Kersten P.J., Kirk T.K. Involvement of a New Enzyme, Glyoxal Oxidase, in Extracellular $\mathrm{H} 2 \mathrm{O} 2$ Production by Phanerochaete Chrysosporium // Journal of Bacteriology. 1987. Vol. 169. Issue 5. P. 2195-2201. DOI: 10.1128/jb.169.5. 2195-2201.1987

5. Lesin V.I., Pisarenko L.M., Kasaikina O.T. Colloidal Catalysts Based on Iron (III) Oxides. 1. Decomposition of Hydrogen Peroxide // Colloid Journal. 2012. Vol. 74. Issue 1. P. 85-90. DOI: 10.1134/S1061933X12010103.

6. Pisarenko L.M., Lesin V.I., Kasaikina O.T. Oxidative Treatment of Biomass using Catalysts based on Iron (III) Oxides // Russian Chemical Bulletin. 2014. Vol. 63. Issue 3. P. 688-692. DOI: 10.1007/s11172-014-0492-z. 
7. Kasaikina O.T., Pisarenko L.M., Lesin V.I. Colloidal Catalysts Based on Iron (III) Oxides. 2. Peculiarities of Catalyzed Oxidation of Palm Oil // Colloid Journal. 2012. Vol. 74. Issue 4. P. 483-488. DOI: 10.1134/S1061933X12040084.

8. Пат. 2425715 РФ, МПК В 01 J 37/04. Синтез многофункционального самонастраивающегося катализатора окислительного крекинга органического сырья и его применение / В.И. Лесин, Л.М. Писаренко, О.Т. Касаикина. 2010105825/04, Заявлено 19.02.2010; Опубл. 10.08.2011. Бюл. 22.

9. Nassar N.N., Hassan A., Carbognani L., Lopes-Linares F., PereiroAlmeo P. Iron Oxide Nanoparticles for Rapid Adsorption and Enhanced Catalytic Oxidation of Thermally Cracked Asphaltens // Fuel. 2012. Vol. 95. P. 257-262. DOI: 10.1016/j.fuel.2011.09.022.

10. Nassar N.N., Hassan A., Pereiro-Almeo P. Comparative Oxidation of Adsorbed Asphaltens Onto Transition Metal Oxide Nanoparticles // Colloids and Surfaces A: Physicochemical and Engineering Aspects. 2011. Vol. 384. Issue 13. P. 145-149. DOI: 10.1016/j.colsurfa.2011.03.049.

11. Лесин В.И. Физико-химический механизма действия магнитной обработки на процесс отложения парафинов в насосно-компрессорных трубах нефтяных скважин // Сетевое издание «Нефтегазовое дело». 2020. № 2. C. 99-121. URL: http://ogbus.ru/files/ogbus/issues/2_2020/ogbus_ 2_2020_p99-121.pdf (дата обращения: 11.01.2021). DOI: 10.17122/ogbus2020-2-99-121.

\section{References}

1. Lin S.S., Gurol M.D. Catalytic Decomposition of Hydrogen Peroxide on Iron Oxide: Kinetics, Mechanism, and Implications. Environmental Science and Technology, 1998, Vol. 32, pp. 1417-1423. DOI: 10.1021/es970648k.

2. Kirk T.K., Farrell G. Enzymatic «Combustion»: The Microbial Degradation of Lignin. Annual Review of Microbiology, 1987, Vol. 41, pp. 465-505. DOI: 10.1146/annurev.mi.41.100187.002341. 
3. Kwan W.P., Voelker B.M. Decomposition of Hydrogene Peroxide and Organic Compaunds in the Presence of Iron and Ferrihydrite. Environtal Science and Technology, 2002, Vol. 36 (7), pp. 1467-1476. DOI: 10.1021/es011109p.

4. Kersten P.J., Kirk T.K. Involvement of a New Enzyme, Glyoxal Oxidase, in Extracellular $\mathrm{H} 2 \mathrm{O} 2$ Production by Phanerochaete Chrysosporium. Journal of Bacteriology, 1987, Vol. 169, Issue 5, pp. 2195-2201. DOI: 10.1128/jb.169.5.2195-2201.1987

5. Lesin V.I., Pisarenko L.M., Kasaikina O.T. Colloidal Catalysts Based on Iron (III) Oxides. 1. Decomposition of Hydrogen Peroxide. Colloid Journal, 2012, Vol. 74, Issue 1, pp. 85-90. DOI: 10.1134/S1061933X12010103.

6. Pisarenko L.M., Lesin V.I., Kasaikina O.T. Oxidative Treatment Of Biomass Using Catalysts Based On Iron(III) Oxides. Russian Chemical Bulletin, 2014, Vol. 63, Issue 3, pp. 688-692. DOI: 10.1007/s11172-014-0492-z.

7. Kasaikina O.T., Pisarenko L.M., Lesin V.I. Colloidal Catalysts Based on Iron (III) Oxides. 2. Peculiarities of Catalyzed Oxidation of Palm Oil. Colloid Journal, 2012, Vol. 74, Issue 4, pp. 483-488. DOI: 10.1134/S1061933X12040084.

8. Lesin V.I., Pisarenko L.M., Kasaikina O.T. Sintez mnogofunktsional'nogo samonastraivayushchegosya katalizatora okislitel'nogo krekinga organicheskogo syr'ya i ego primenenie [Synthesis of a Multifunctional Self-Tuning Catalyst for the Oxidative Cracking of Organic Raw Materials and its Application]. Patent RF, No. 2425715, 2011. [in Russian].

9. Nassar N.N., Hassan A., Carbognani L., Lopes-Linares F., Pereiro-Almeo P. Iron Oxide Nanoparticles for Rapid Adsorption and Enhanced Catalytic Oxidation of Thermally Cracked Asphaltens. Fuel, 2012, Vol. 95, pp. 257-262. DOI: 10.1016/j.fuel.2011.09.022.

10. Nassar N.N., Hassan A., Pereiro-Almeo P. Comparative Oxidation of Adsorbed Asphaltens Onto Transition Metal Oxide Nanoparticles. Colloids and Surfaces A: Physicochemical and Engineering Aspects, 2011, Vol. 384, Issue 1-3, pp. 145-149. DOI: 10.1016/j.colsurfa.2011.03.049. 
11. Lesin V.I. Fiziko-khimicheskii mekhanizma deistviya magnitnoi obrabotki na protsess otlozheniya parafinov $\mathrm{v}$ nasosno-kompressornykh trubakh neftyanykh skvazhin [Physical and Chemical Mechanism of Magnetic Treatment Action on the Paraffin Deposition Process in Oil Well Production Tubes]. Setevoe izdanie «Neftegazovoe delo»-Online Edition «Oil and Gas Business», 2020, No. 2, pp. 99121. URL: http://ogbus.ru/files/ogbus/issues/2_2020/ogbus_2_2020_p99-121.pdf (accessed 11.01.2021). DOI: 10.17122/ogbus-2020-2-99-121. [in Russian].

\section{Сведения об авторах}

\section{About the authors}

Лесин Виктор Иванович, канд. физ.-мат. наук, ведущий научный сотрудник, Институт проблем нефти и газа Российской Академии наук (ИПНГ РАН), г. Москва, Российская Федерация

Viktor I. Lesin, Candidate of Physics and Mathematics Sciences, Leading Researcher, Oil and Gas Research Institute of Russian Academy of Sciences, Moscow, Russian Federation

e-mail: vilesin@inbox.ru

Лесин Сергей Викторович, инженер, аффилиация, Российский государственный университет нефти и газа им. И.М. Губкина, г. Москва, Российская Федерация

Sergey V. Lesin, engineer, affiliation National University of Oil and Gas «Gubkin University», Moscow, Russian Federation

e-mail: lesinsv@gmail.com 